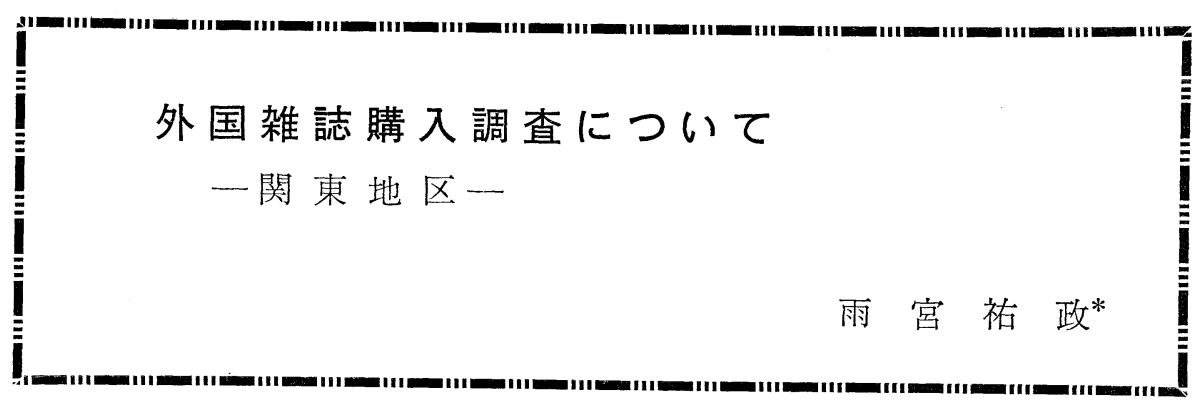

はじめに

外国雑誌を適正な価格で購入し，正確に入 手するといらことは当然なことでありながら 今日なお種々の問題を含んでいることは誠に 遺憾なことである。このことを是非なんとか いたしたいと考えている折，たまたま関東区 会の席上で話題となり調査することが議せら れ，東京慈恵医科大学の向井茂氏が該資料の 原案を作成し, 東京医科歯科大学が関東区世 話役といらことで筆者の手許において調查材 料の収集とまとめを行なったのをこのような 形で発表する次第である。

ここにこの調查について問題となる点も多 かろらと思われるので, 利用方法上注意願い たいことを附記しておく。即ち，ご覧いただ けば自明の通り僅々 20 点といら極めて一部 分の外国雑誌のことについて眺望した限り， 決してこれが無欠のデータであると判断する ことは危険であるのみでなく，予約購入契約 で相互に結び合ったとは言え，経費の支払方 法がそれぞれの機関に差異があり，また，見積 り当初の契約を十分に履行しない面があると ころから思惟すると，これらの調查が果して 妥当なものであるか疑念なしとは考えられな い。刎論このような調査においてついやされ た効果は，図書館側で得た収穫としては大き なものがある他面，業者側へ与えた反省資料 として決してゆるがせにできないものがある と信ずる。そうは言いながら, 未熟な内面が存 する以上，利用されるに際して調査結果説明

* Sukemasa AMAMIYA 東京医科歯科大学
を通しよく考察されるよう望むわけである。

\section{結 果の分析}

この調查目的は，重要文献で，かつ，利用 頻度の高いもの 20 点を選てで，それらの文 献をどのように経済的に入手をし，利用体制 を整えているかを知ろらとすると共に，予約 購入とは何かということを明確に答えるすべ を追究するにある。従って，ここにまとめら れたそれぞれの調査データは，一応，予約購 入方式の実体をあかしているものである。

それでは，これからこの調査にあらわれた 課題の核心にふれながら，解明してゆこう。

先ず，各機関が外国雑誌を限りある経費 でより多数のものを入手しよらとするために 払ら金銭的，精神的努力は，並夕大抵のこと ではないが，今回の調查対象とした別揭資料 20 点に支出された金額をみると, 総計 6,362 , 705 円で，らち大学が 4, 828, 225 円，病院・ 研究所が 1,534, 480 円であることは，易々と みることは早計であろら。また，このように 多額の経費を取り引きする業者も，ここに意 を集中することのあるという点は，否とはい えないと思う。な抒，これを平均にしてみる と, 大学関係で 30 万円, 病院 - 研究所機関 で 22 万円となり，また，全機関平均で 28 万 円である。従って，1種類 18,000 円弱とな るので少額どころではなく配慮を吝ってはな らない金額というべきであろら。これを機関 別に执いての開きの巾でみると，1 種類 15,0 00〜12,000 円となり，これを更に実証する例 として昭和 42 年度に正規契約を予定してい 
る東京医科雪科大学の諸契約高は, 種類にし て 625, 点数で 962 の 13, 074, 450 円で, その 1 点平均額 13, 590 円に比して自明のように まことに安易な契約高とはいえないようであ る。

つぎに分析調査結果をみると，総合な面で 第 1 表拉よび第 2 表に示されるところによれ ば，前者にあっては誌名 $2 ， 6 ， 9 ， 11 ， 12$, $13 ， 14 ， 15 ， 19$, 後者にあっては 4, 5, 6, 11，12，14等が価格較差が目だつものであ る。しかも，前者が全体の 2 分の 1 に対し， 後者は 3 分の 1 弱の開きを示していること は，裏を返えせば注文者である機関側も業者 側もいろいろと問題をもち，いい分もあろう が, 課題の中心点が最終的には 3 分の 1 前後 に解決方法を強く打ち出せばよいと断定し得 られるよらである。な敃，このようにして二 者を比較して分析結果の大方をまとめて論ず るとき，機関での契約の仕方や業者の取り引 きでの勘案などによる差異原因が生じている ことはいらまでもなく，その顕著な実証とし て平均值 $5,6,12,14$ が価格高低の開きを 示していることである。即ち， 5,6 は案外契 約高が安くなかったといえるし，反対に 12,14は安く契約されたものが多かったと論 断し得るわけであるら。更に, これを第 5 表, 第 6 表，第 7 表，第 8 表に亘る前金払，後金 払，分割払，混合払の契約別のそれぞれを眺 めるとき，第 1 表，第 2 表をよく裏書きして いると思う。価格較差の強くみえるのは, 殊 に第 8 表の混合払であることに注目されるだ ろら。このことは，第 3 表，第 4 表にみる契 約別支払合計額比較によく示されていると思 ら。また，第 16 表，第 17 表にみる業者側に みる契約別による機関の支払区分が混合払が 多いといらことと関連しているといってよか ろら。

概略グラフ表で大まかに説明したので具体 性を離れたため，とらえにくいところがあっ たかと考えるが，特に機関・業者双方におい て今後研究し, 検諳を要するのは, はじめに
おことわりしておいたように，種々雑多の条 件が内在しているほか，この調査が原価まで 併記されてなされたものでないことが意味を 減殺しているかもしれない。ともかく，この ような結果をまとめたということでプラス面 を提示したものであろら。

殊に金額較差のはるかに開いている 2 の J. A. M. A. や 9 の Biochim. Biophys. Acta および 16 の Circulation の 3 点は疑問を多 く含んでいる。もっとも，これらの誌類は， 一つは原価の相異と誌類のもつ性質といらか 条件を伴らことによる取り扱いの差異などが 左右しているので，機関の十分な心得ある注 意によることが肝要であり，また，業者もと れに沿らた機関の意志を喚起して誤りない金 額を示すべきだと思う。随って国立機関にあ っては，誌類の特殊事情を勘案して随意契約 といら方式で，支払方法の区分によりその年 度の終りを期し精算処理を会計面で行ならと いらことをし，予想ないし，予測される諸事 項を円滑に運び得るように努めているのであ る。このよらな煩さなことをしなければなら ないといらことがどの位あるか子該調查で明 示されているについて予約購入といらことの 意味を改めて考学る必要が同時にあろう。

最後に 20 点の誌類について契約高がどの よらになされているかをみたのが，第 9 表， 第 10 表，第 11 表，第 12 表,第 13 表，第 14 表，第 15 表である。これらによって知られ るように，前述同様混合払に集中していると 共に, 前金払, 後金払も多くみられる。そし て問題点を含む誌類も誌名 $4,5,6,9 ， 11$, $12 ， 13 ， 14 ， 15 ， 19$ などとなっている。それ に全般的に眺めて老舗は取り引きも多く契約 高も多いながら，平均して上昇にあるが，取 り引きでは余りひけをとらない新進若しくは 小社では，逆に契約高の割に安值であるとい うことが知られる。このことは, 機関にしろ, 業者にしろ名称を記号化しているのでおわか りにくいところがあろらが，このように述べ れば推測されることだろう。 


\section{予約購入の問題点}

ここに予約購入ということになるが，これ には次のよらなことがらくまれているといっ てよからう。

1）会計的の立場

2）学術資料の立場

このほかに利用者であり，使用者である研 究者の要望を十分に充たすることに対する立 場が考兄られねばならないと思う。

1）の会計的な処理にしても，単に金員で 片のつくことではない。学術資料としての誌 類が何等の事故がなく円滑に納入されること が先決である。これは自然科学, 応用科学系 列の学術資料入のすべてにあてはまるもので あろう。従って，適切，不当でない金額が割 り出され, 遅滞ない現品納入が肝要であり, また，価格が安定していることである。万一 に価格変動があったり，何等かの理由で事故 が生じた折は，速かとそのことを処理するこ とであるが，それができなかったり，予め定

(第 1 表) 未区分(共通)最高・最低金額比較

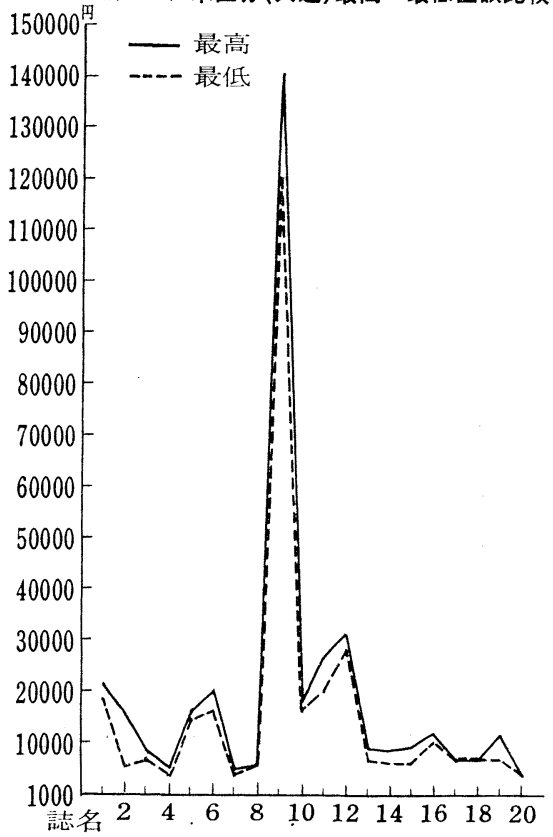

められた期限までに手笘がなし得ないといら 場合は，精算による処理が当然あるべきであ る。また，契約時の金額と相異による不足は それぞれの証書類の提示により支払われなけ ればならないであろう。これらが現在取り扱 われている予約購入上のすべてである。そこ には，ぞこまでも物件意識の何物も存しな い。いわゆる物件としての価值のみの判断に よっている。

1）に対し，2）は単に物件というょりは, 生命の込んだ物件であり，当然精神的な面を 加味したものないしは，文化財的考学をもっ て処理するということで, 納入者である業者 に対する条件は，1）に示したと同様ではあ るが，態度に学術資料尊重性を多大評価する ところからなされることだと思う。

いらならば, 経理担当の側と図書担当の側 の見解に基く相異であろらが，むしろ最近は 前者に考光をもつ図書館職員も多い。この上 らなことが予約購入全般に混迷させるものが 存するといって過言はないようだ。

(第 2 表) 予約購入契約最高·最低額平均価格比較

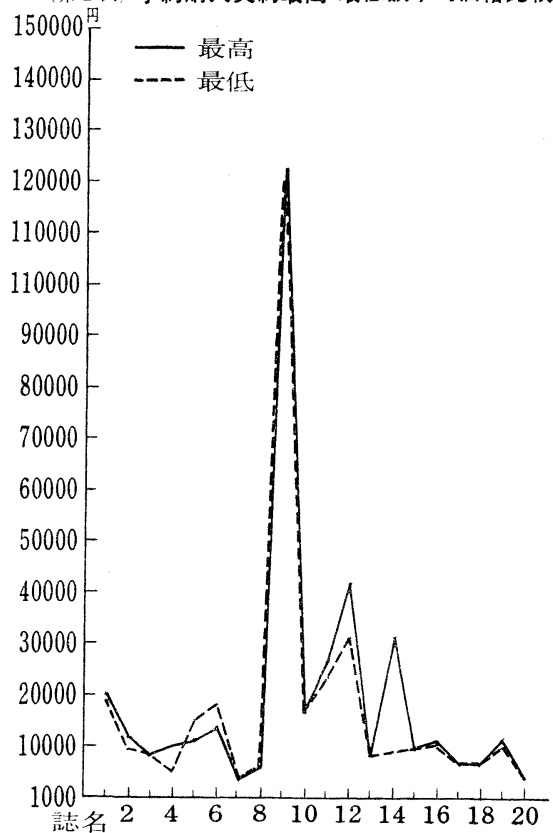




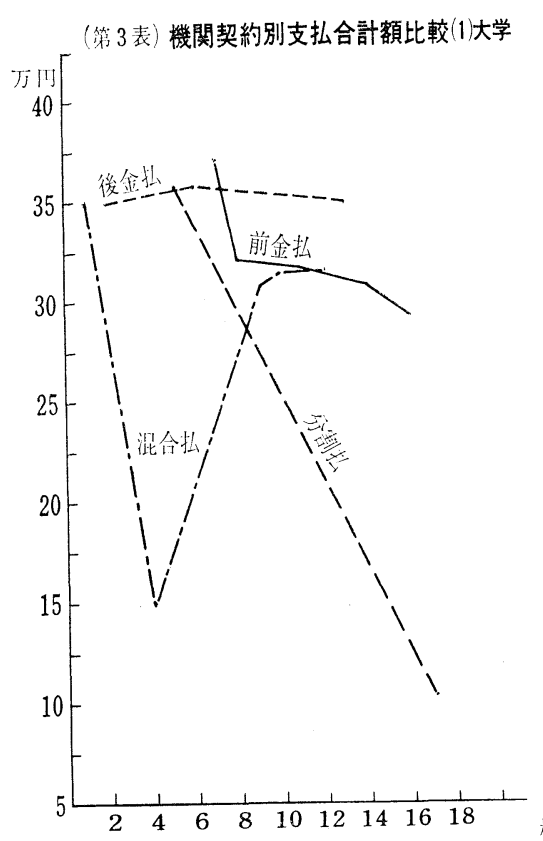

(第 4 表) 機関契約別支払合計額比較(2)病院・研究所

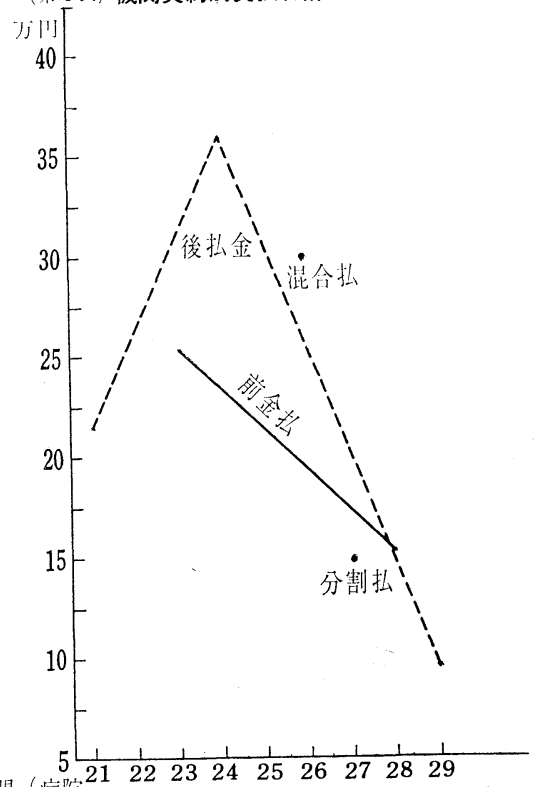
機関 (病院

(第 5 表) 契約別最高・最低金額比較 (1)前金払

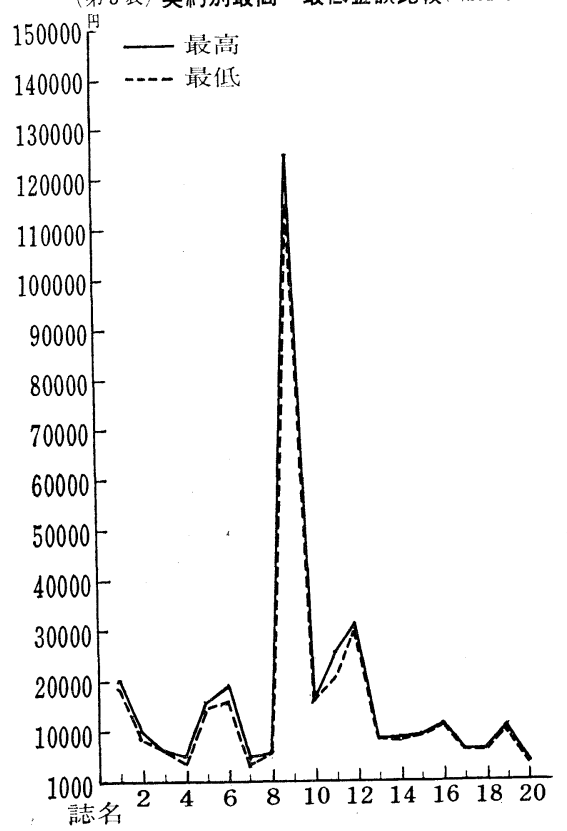

(第 6 表) 契約別最高・最低金額比較( 2 後金払

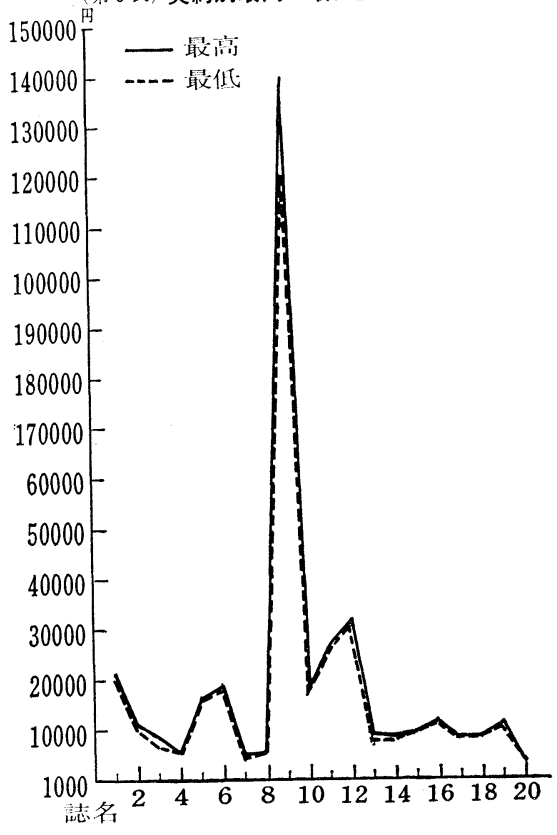



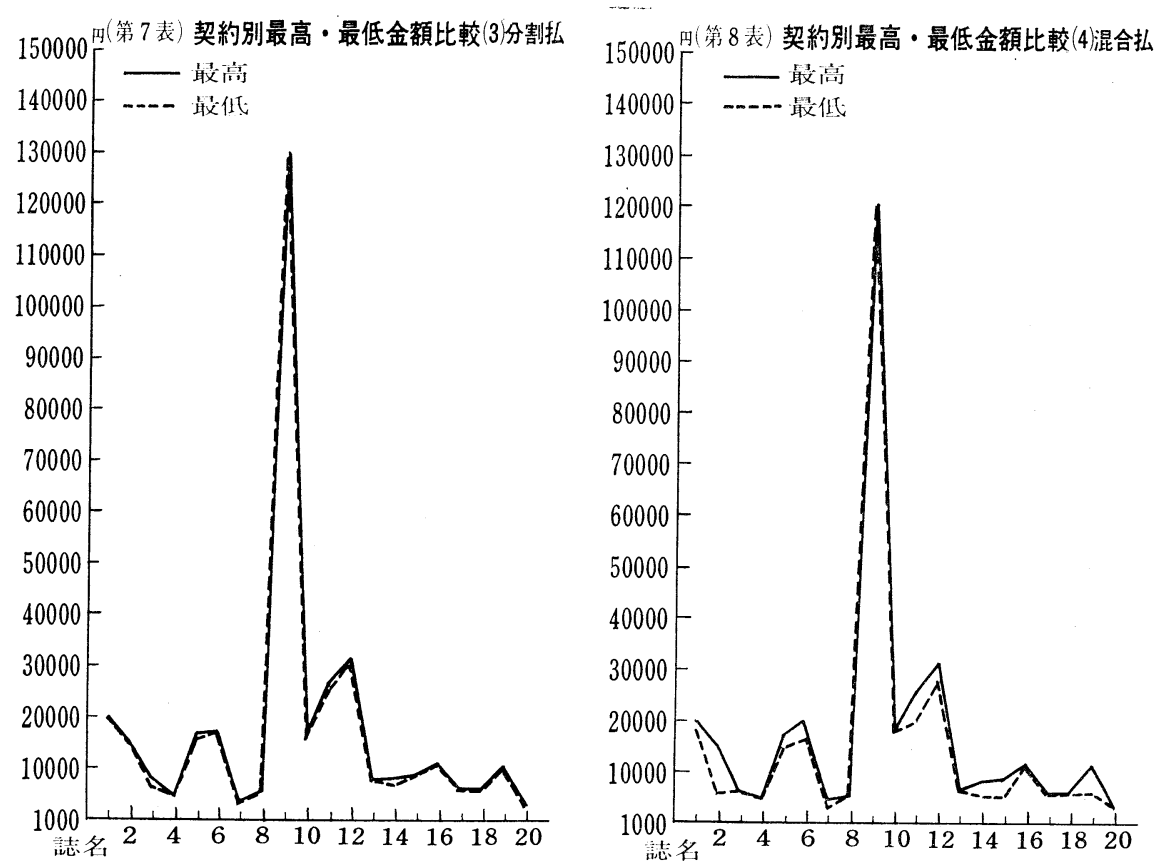

(第 9 表) 業者別予約購入価格比較 (1)前金払A, B, D
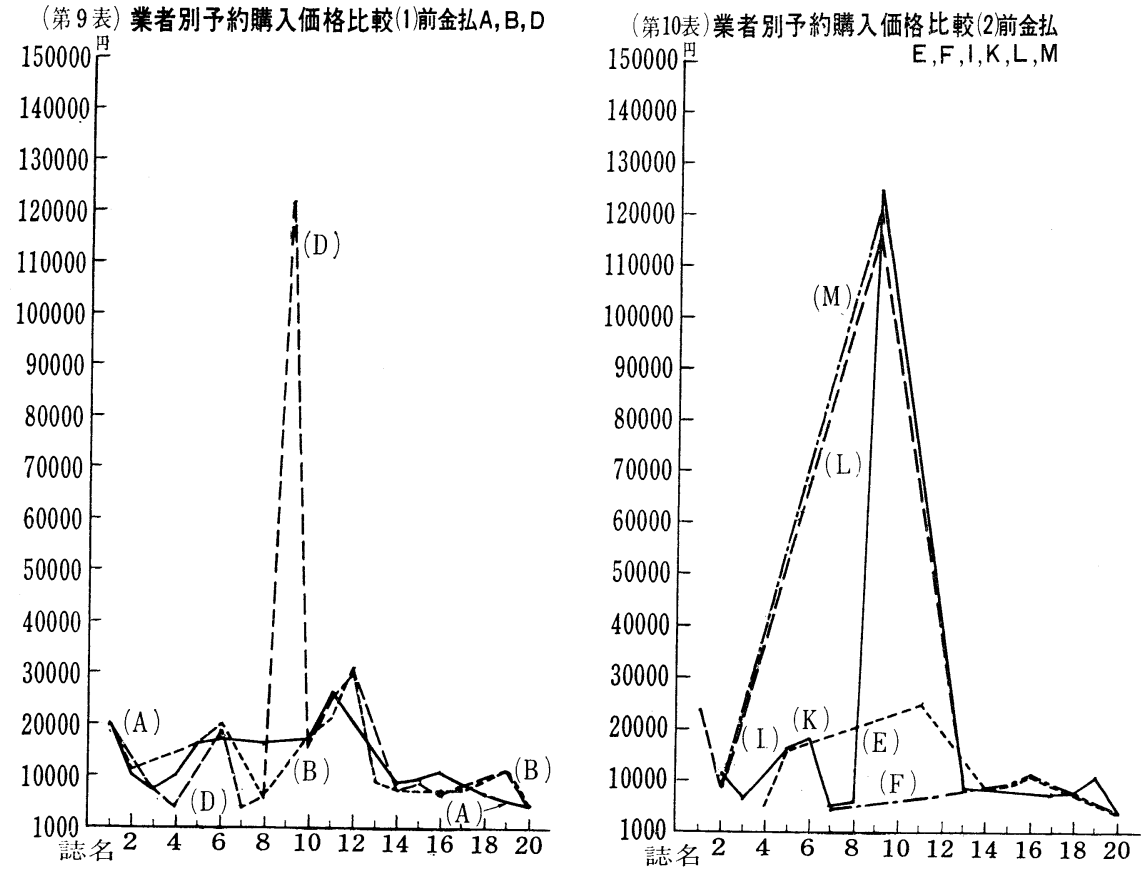

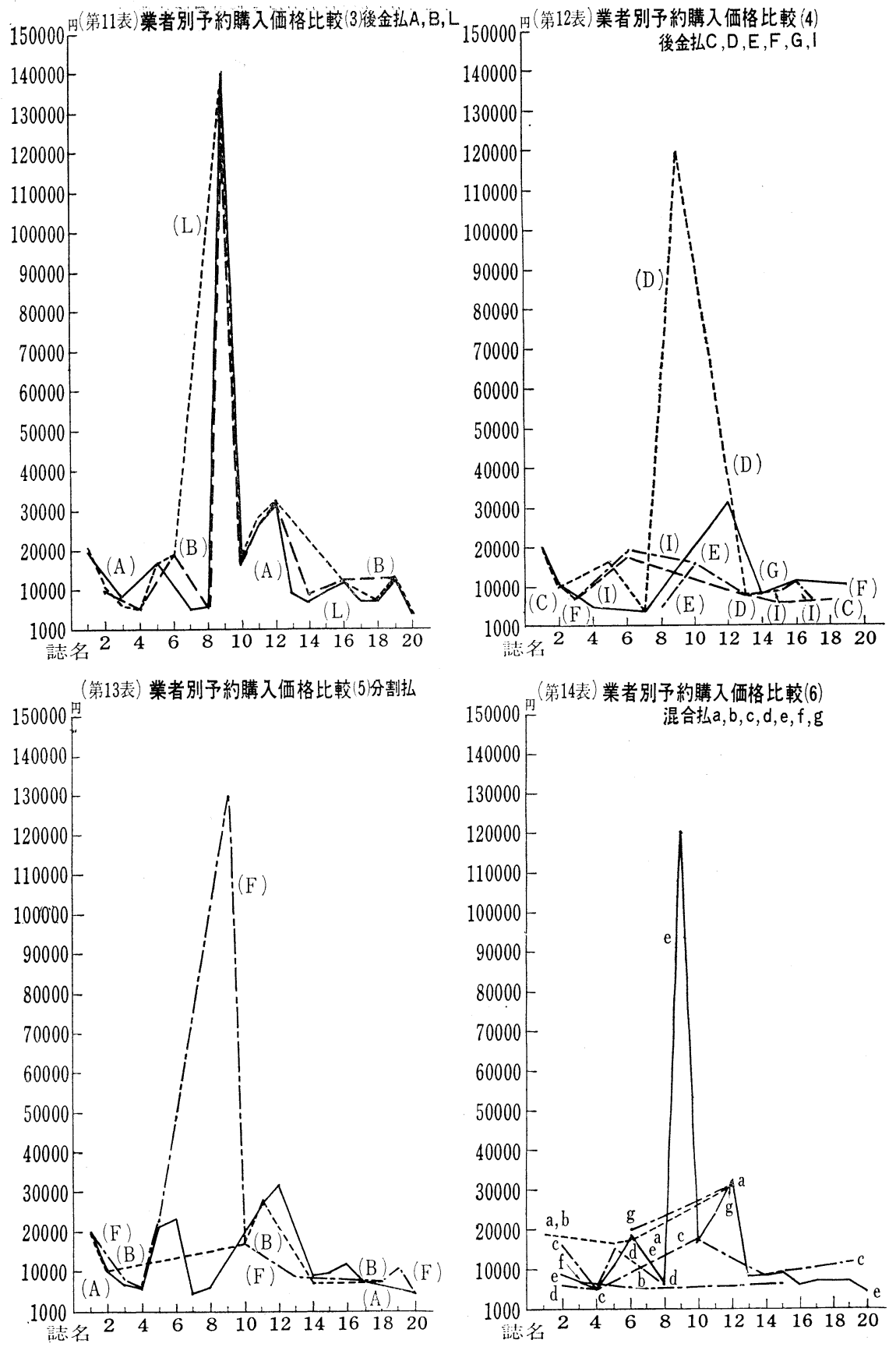


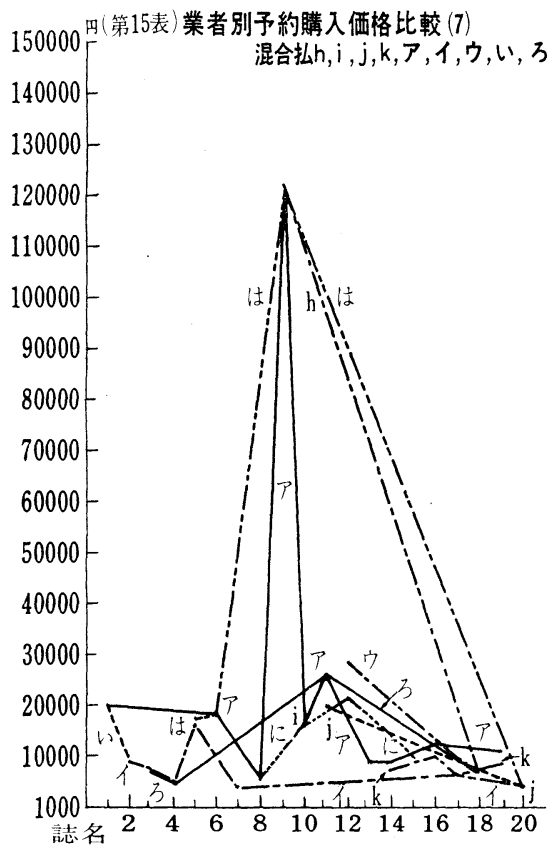

(第17表) 支払別業者契約高合計金額比較（2）混合払

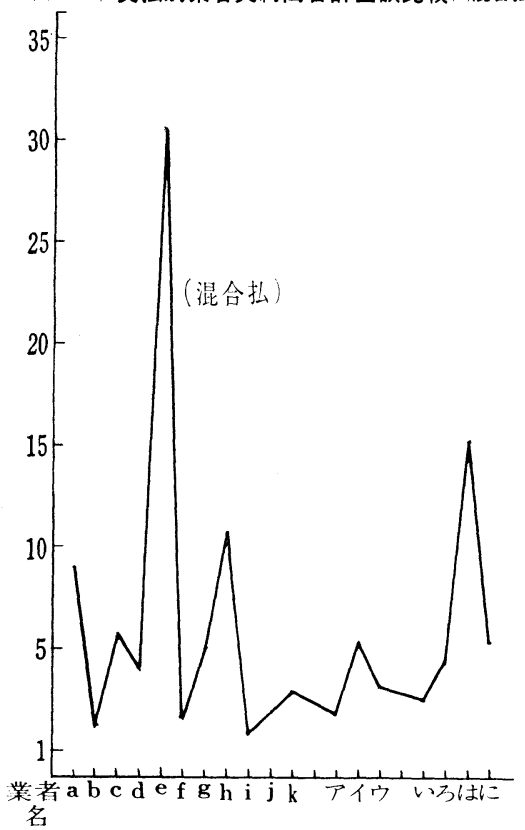

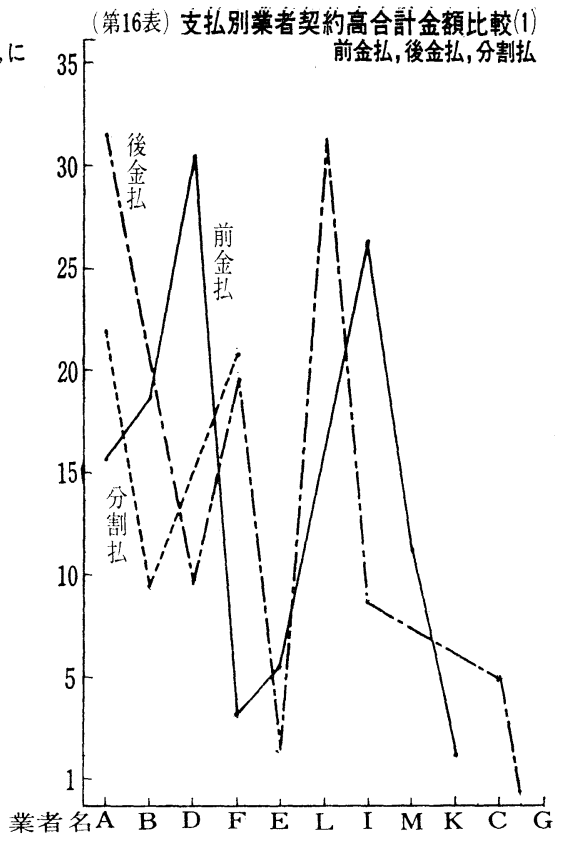

\section{調査対象の外国雑誌名一覧}

1. Journal of Biological Chemistry.

2. Journal of the American Medical Association.

3. Proceedings of the Society for Experimental Biology and Medi. cine.

4. Lancet.

5. Nature.

6. American Journal of Physiology.

7. New England Journal of Medicine.

8. Journal of $\mathrm{Clinical}$ Investigation.

9. Biochimica et Biophysica Acta.

10. Journal of Experimental Medi. cine.

11. Biochemical Journal.

12. Journal of Physiology.

13. Annals of Surgery.

14. American Journal of Medicine.

15. British Medical Journal.

16. Circulation.

17. Surgery, Gynecology and Obstet. rics.

18. Cancer Research.

19. Endocrinology.

20. Science. 